\title{
Guidelines for Landscape Management in the Areas of Rural-Urban Interface : Continuity and Innovation
}

\author{
Erika Zaleskienė, Indrè Gražulevičiūtė-Vileniškè, Kaunas University of Technology
}

\begin{abstract}
The focus of the present research is rapidly emerging rurban landscapes. In this research we apply the concepts of resilience of socio-ecosystems, landscape sustainability, alternative landscapes etc. in order to formulate general guidelines for rurban landscape management. The formulated guidelines for rurban landscape management consist of the basis for management providing guiding and integrating aspects and the management goals in six interconnected areas - environment, economics, equity, aesthetics, experience, and ethics.
\end{abstract}

Keywords - Rural-urban interface, rurban landscape, landscape management, sustainability, resilience, socio-ecosystem.

The European Landscape Convention encouraged landscape researchers and practitioners to look more carefully at very different types of landscapes; according to L. Musacchio [1], the attention is increasingly directed towards human-dominated environments and their complex problems including the effects and impacts of urbanization such as rapidly emerging and changing landscapes in the areas of rural-urban interface. D. Low Choy and M. Buxton [2] underline that these rurban landscapes and the related complex social and environmental issues call for rethinking of traditional landscape planning and management approaches. Considering this, our research was aimed at formulating general guidelines for landscape management in the areas of rural-urban interface.

\section{Methods}

In this research, using the experience of the Resilience Alliance (an interdisciplinary network of scientists and practitioners) [3], D. Low Choy and M. Buxton [2] and L. Musacchio [1], we view rurban landscapes as systems, where the environment (natural, cultivated) and society interact closely - as socio-ecological systems [2-3] or coupled human and natural systems [1]. Based on this view, we employ general landscape sustainability model by L. Musacchio [1] "six Es of landscape sustainability" and in its framework provide the guidelines for rurban landscape management.

\section{RESULTS}

The general guidelines for rurban landscape management consist of two parts: the basis for management providing guiding and integrating aspects and the management goals in six interconnected areas distinguished by L. Musacchio [1] environment, economics, equity, aesthetics, experience, and ethics.

\section{A. The Basis for Management of Rurban Landscapes}

Understanding of rurban landscapes is one of the basic premises for their appropriate management. We see rurban landscapes as having particular features as a landscape type influenced or determined both by global and local aspects. The rurban landscapes can be characterized as remnant (presence of rural dimension), transient (rapid changes, transition from rural to urban), contested (conflicts between urban and rural uses, lifestyles, aesthetics etc.), complex (have both urban and rural features and new qualities, characteristic solely to these landscapes), interdependent (links to and dependence on the urban area) [4]. We also argue that rurban landscapes can be analyzed from three points of view: global (what these landscapes have in common around the world), local peculiarities (peculiar aspects of specific rurban areas determined by local history, social, economic, cultural, and other factors), and identity (unique and valuable features of the rurban space of the country that should be maintained). Consequently, the management solutions for rurban landscapes must be based on their particular features and global (international, supra-national regional), local (national, urban settlement level), and identity (national, urban settlement level) aspects of these landscapes (Fig. 1).

Holistic approach. The understanding of the features and dimensions of rurban landscape implies the holistic approach; one of the ways to address landscape as a whole is contemporary notion of landscape sustainability. According to L. Musacchio [1], in landscape research and practice, scientists have reinterpreted the definition of sustainable development to include the holistic basis of landscapes; in this context she presents landscape sustainability model "six Es of landscape sustainability" integrating environment, economics, equity, aesthetics, experience, and ethics and argues that one of the great challenges will be how to operationalize the environmental, economic, equity, aesthetic, experiential, and ethical performance of designed landscapes as sustainable landscapes in an urbanizing world. Fig. 2 shows six dimensions of rurban landscape [1], in which sustainability should be achieved, and corresponding contemporary features of these landscapes, which should be mitigated, transformed or creatively employed developing sustainable rurban landscapes as a new

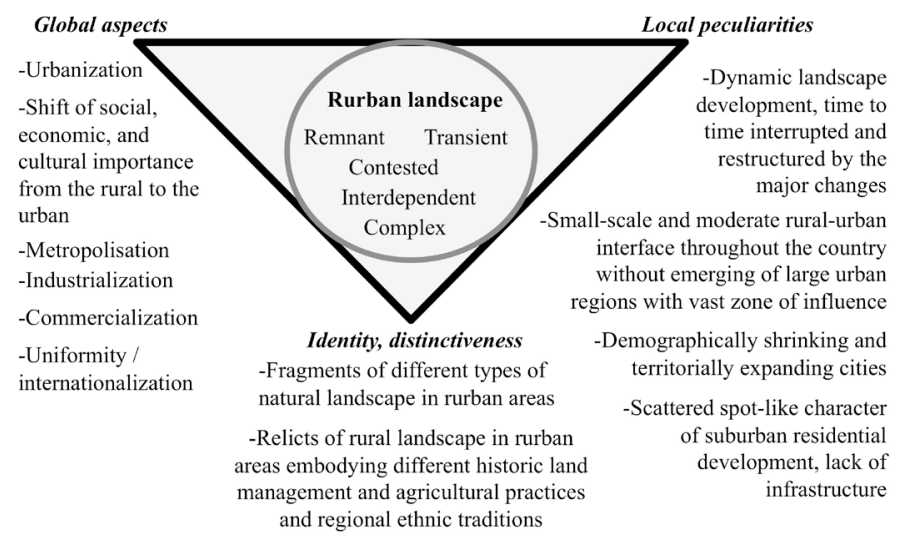

Fig. 1. Features of rurban landscapes (case of Lithuania). 


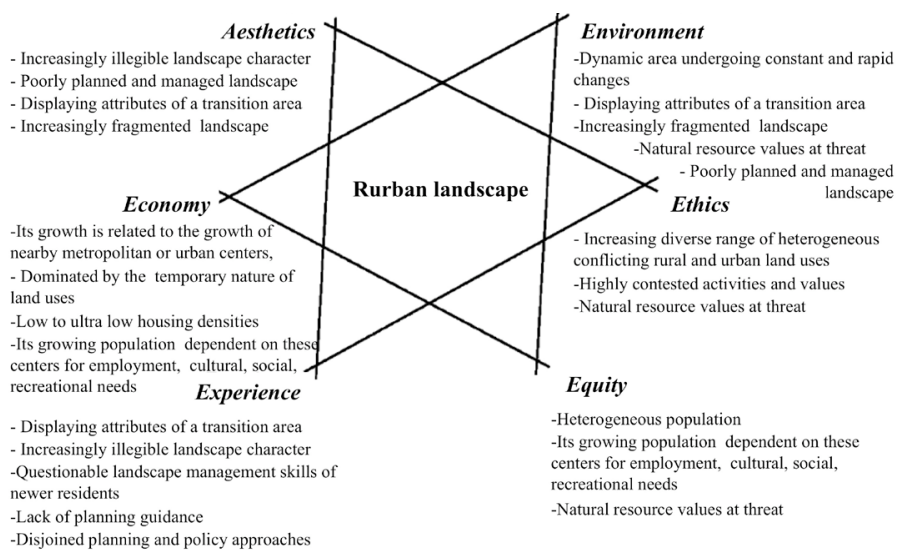

Fig. 2. Six dimensions of rurban landscape sustainability [1] and related features of contemporary rurban landscapes [2].

landscape type. Looking at rurban landscapes as a new landscape type and at the prospects of their sustainable development another holistic concept - resilience of socio-ecological systems [2-3] or coupled human and natural systems [1] - should be integrated in this research. Resilience of socio-ecological systems is a basis for their sustainability and is defined as the capacity of such system to tolerate disturbance without collapsing into a qualitatively different state that is controlled by a different set of processes [3]. From the resilience point of view, the landscapes that can be defined as rurban have lost the above-described capacity to resist changes and are undergoing qualitative transformations from rural into urbanized areas. Consequently, the sustainable development of rurban landscapes requires:

1) regulated qualitative transformations into sustainable rurban landscapes as a distinctive landscape type;

2) maintenance of resilience once this transformation is achieved.

\section{B. The Management Goals of Rurban Landscapes}

The above-presented basis for management of rurban landscapes - understanding and holistic approach - require establishing rurban landscape management goals in order to develop new category of sustainable landscapes and increase their resilience in all six sustainability dimensions.

Environment. In this research, the environment is seen as encompassing both human and natural components and their interactions at different scales. Considering this, the goals of sustainable development of rurban environment are:

- Multiscale planning of development or systematic approach considering different territorial levels, which is a more adequate approach to face and manage complex systems [6], such as rurban landscapes.

- Integrated planning and management at different scales in order to avoid institutional fragmentation and conflicts.

- View the question of rural-urban interface in the context of development of the entire country or a broader region. The strategic documents of regional development and land use should guide the decision concerning the development of rurban areas.

- Balanced regional development of rural-urban interface. It is clear that in the future urban expansion and development of rural-urban interface will be most relevant for large urban centers due to rapid territorial expansion and importance of these cities in contemporary strategies and plans; however, in order to avoid the situation when large cities grow and expand at the expense of declining regions, the goal of more even regional development, placing the emphasis on small and medium size cities and towns, should be paid special attention.

- Development of the areas of rural-urban interface should be considered at the city/urban settlement level, i.e. integrated into the development strategy of a particular urban area.

- Reserved attitude towards further territorial urban expansion developing rurban areas corresponding to general sociodemographic trends of the country and the city and beneficial from the ecological (energy savings, preservation of natural areas and habitats etc.) and other points of view.

- Application of the concept of sustainable socio-ecosystem at the local level - the idea that people and other living organisms can coexist in mutually supportive habitats [1], in a sustainable world of designed ecosystems $[1,6]$.

- Development of diverse and multifunctional socioecological systems and contemporary cultural landscapes in rurban areas, as the key to resilience in socio-ecological systems is diversity [3]. According to E. Berte et al. [5], cultural landscapes - integrated landscapes, where natural and social processes are compatible - are characterized by the multifunctionality, which is determined by a variety of uses. They note that contemporary cultural landscapes originate from integrated goals, when physic, ecosystem, and social elements are planned together.

- Valuable natural areas, the relicts of rural landscape, renaturalized areas in the rurban zones should be preserved and simultaneously serve for protection of biodiversity and eco-compensation and for recreation and education. These green rurban areas should make an integral part of the natural framework of the city.

- Preservation of landscape heritage in rurban socioecosystems including the relicts of historic rural landscape types.

- Quality and sustainability of human living environment in the rural-urban interface zones including the beneficial ecological situation, polycentric structure of emerging rurban areas based on the ideas of neighborhood unit [7], self-sufficient rurban settlements, the relicts of historic rural landscape - buildings, ensembles - serving as centers or important nods of emerging neighborhoods.

- Ecological land use, sustainable agriculture.

Economics. Economic dimension in this research concerns the production, distribution and consumption of goods and services in an exchange economy and the behavior of individuals, groups, and organizations, when they manage or use scarce resources, to achieve the desired ends. In this context, the goals of sustainable economic development of rurban areas are:

- Self-sufficiency of communities in the rurban areas. Self-sufficiency would depend on the distance from the urban center - the larger the distance from the urban area, the more self-sufficient communities should emerge. Self-sufficiency of rurban communities should include 
the diversification of economic activities, creating and broadening of the employment base, provision of services and lessening the need of commuting [2]. This would help to stabilize the changes and increase economic resilience in the rurban areas.

- Self-sufficiency of communities in the rurban areas is closely linked with the above-mentioned multifunctionality. The multiplicity of complementary functions - residential, cultural, recreational, commercial, productive, agricultural, etc. - would contribute both to the quality of life, self sufficiency, and the links with the city of the rurban areas.

- Innovations are important both for the competitiveness and well-being of the community and for the continuous evolution of the landscape. Such innovations may include ecological peri-urban and suburban agriculture, nontraditional agriculture (lifestyle horticulture, mushroom growing, snails, earthworm's farms, harvesting of solar energy on the rooftops, etc.). The relicts of historic rural landscape that had lost their original functions can be adapted to new needs without losing their identity; historic rural buildings, such as manor houses or homesteads, can be used for tourism or adapted to the needs of communities. A joint form of peri-urban farming and agricultural tourism can be developed.

- Mutually beneficial links between the city and the surrounding rurban areas through production-consumption, exchange of services, locally oriented agriculture, and recreation: the rurban areas may accommodate selfsufficient communities with infrastructure and workplaces and also provide recreational areas and agricultural production for the city.

- Rational use of resources including the use of existing infrastructure and buildings, adaptation and re-use of abandoned buildings, preservation of agricultural land.

Equity. Equity is viewed here as the social dimension of rurban landscape sustainability, as social justice. The social goals of rurban landscape development are:

- Perceived quality of life, consisting of numerous abovementioned factors including self-sufficient communities, economic well-being, recreation possibilities, beneficial ecological situation, valuable natural and cultural landscapes for the present and future generations.

- Maintenance of social diversity and diversity of lifestyles in rurban areas avoiding or mitigating segregation or conflicts between new and local residents.

- Development of communities, formation of local institutions, organizations, and social links that help rurban areas and local communities to creatively adapt and to improve resilience and persistence [1].

- Involvement of rurban communities in decision making.

Aesthetics. Rurban landscape aesthetics here is seen as the landscape quality perceived using all human senses (including sight) [8] also emphasizing the importance of informational content and legibility of landscapes. The main aesthetic goals of development of rurban landscape are:

- Aesthetic development must be seen as an integral part of the overall sustainable development of rurban landscapes and must be integrated in every stage of the general sequence of landscape development process from its beginning.

- Development of ecoaesthetic rurban landscapes - socioecosystems that integrate aesthetic quality and ecological health.

- The local identity (the identity of particular country, region or settlement), legibility (identity of particular landscape type), and distinctive aesthetic image of rurban landscapes should become integral parts of rurban landscape aesthetics.

- Preservation of landscape heritage, both natural and cultural, should play an important part in rurban landscape identity, legibility, and distinctiveness.

- Preservation of rural dimension as one of the sources of identity of rurban landscapes.

- Search for corresponding aesthetic images for rurban landscapes including landscape architecture, planning, and architectural innovations. This also includes the search for specific architecture and urbanism solutions, reflecting the local identity and specific identity of rurban areas.

- Humanization of living and working environment, mitigation of visual pollution characteristic to rurban landscapes (abandoned farm buildings, aggressive infrastructure objects, etc.).

- Optimization of visual diversity. The historic relicts of rural landscape, fragments of natural landscape, functioning agricultural areas as recognizable and aesthetic objects should play an important role maintaining the psychologically acceptable visual diversity in the rurban areas.

Experience. In this research experience comprises the accumulation of knowledge or skills related to rurban landscapes and/or the apprehension of an object, thought, or emotion through the senses or mind [9]. The main experience related goals of rurban landscape management are:

- Rurban landscapes can be experienced as a new and distinct form of settlement, new type of landscape, not necessarily consumed by the expanding city - neither urban nor rural in a traditional sense. These should be functionally operating but also rich in identity and symbolic meanings landscapes [5]. The concept of alternative landscapes by Musacchio [1] can be used to describe them - such landscapes would introduce new types of nature (for example, renaturalized areas) and reinterpret the cultural meaning of human health, security, multifunctionality, and ecosystem services, they would provide the distinctive places for people in the zones of rural-urban interface that protect different types of biodiversity and cultural diversity, facilitate stress reduction and mental fatigue, and enhance human-nature interactions.

- New experience and skills for multiscale integrated planning and management or rural-urban interface and development and management of such alternative rurban landscapes are needed.

Ethics. Ethics in this research refers to the concepts of right and wrong conduct. The ethical goals related to sustainable development of rurban landscapes are: 
- The need to reconcile the ecological ethics, aesthetics, and functionality in rurban landscapes.

- The ecological education and ecological literacy [2] of residents and users of rurban areas.

- The necessity to coordinate and reconcile different, often contradictory sets of values, lifestyles of rural and new urban residents in rurban areas. The urbanity as a driver of change must be acknowledged; however, the need to preserve rural dimension cannot be neglected.

- The need for ethical innovations, where previous values (both natural and social) are the basis for new coherent solutions [5].

- The need to develop place awareness, topophilia for rurban landscapes.

\section{CONCLusions}

Management of landscapes emerging in the areas of ruralurban interface raises environmental, social challenges and challenges related to identity, locality, and sense of place. The need to respond to these challenges encourages formulating general guidelines for landscape management in the areas of rural-urban interface integrating ecological, social and identity, global and local aspects.

After the analysis of literature and using the experience of the Resilience Alliance, D. Low Choy and M. Buxton, and L. Musacchio, the general guidelines for rurban landscape management were formulated. The first part presents the basis for management - guiding and integrating aspects: understanding of global and local aspects and features of rurban landscape and holistic approach to it based on the concepts of sustainability and the resilience of socio-ecosystems. The second part presents the management goals of rurban landscapes in six interconnected areas - environment, economics, equity, aesthetics, experience, and ethics and demonstrates the importance of both continuity and innovations for these dynamic landscapes. Table I shows rurban landscape management goals according to the dimensions of sustainability and their relevance to different aspects of these landscapes and the biophysical and social features that can decrease resilience these goals are targeted at.

\section{REFERENCES}

1. Musacchio, R. L. The scientific basis for the design of landscape sustainability : A conceptual framework for translational landscape research and practice of designed landscapes and the six Es of landscape sustainability. Landscape Ecology, 2009, vol. 24, pp. 993-1013. http:// dx.doi.org/10.1007/s10980-009-9396-y

2. Low Choy, D., Buxton., M. A resilience approach to peri-urban landscape management. State of Australian Cities National Conference : Melbourne, Australia, 29 November-2 December (C. Whitzman, R. Fincher, ed.). Melbourne: 2011, pp. 1-7.

3. An interdisciplinary network of scientists and practitioners [online] Resilience Alliance [cited 11.03.2014]. http://www.resalliance.org

4. Zaleskienè, E., Kamičaitytè-Virbašienė, J., Graluževičiūtè-Vileniškè, I. Aesthetic aspects of landscapes in the rural-urban interface zones. Acta Biologica Universitatis Daugavpiliensis, 2013, 1(13), pp. 15-30.

5. Berte, E., Panagopoulos, T., Zanon, B. An interpretative model for the management of contemporary cultural landscapes in linear infrastructure projects. Journal of Environmental Engineering and Landscape Management, 2013, 21(4), pp. 248-262. http://dx.doi.org/10.3846/164868 97.2012 .745412

6. Wu, J. Making the case for landscape ecology: an effective approach for urban sustainability. Landscape Journal, 2008, 27(1), pp. 41-50. http:// dx.doi.org/10.3368/1j.27.1.41

7. Patricios, N. Urban design principles of the original neighbourhood concepts. Urban morphology, 2002, 6(1), pp. 21-32.

8. Kamičaitytè-Virbašienė, J. Kraštovaizdžio vizualinès kokybès reguliavimas kraštotvarkoje (Lietuvos pavyzdžiu): daktaro disertacija. Kaunas: Technologija, 2003.

9. Experience [online]. Free Dictionary [cited 03.03.2014]. http://www. thefreedictionary.com/experience

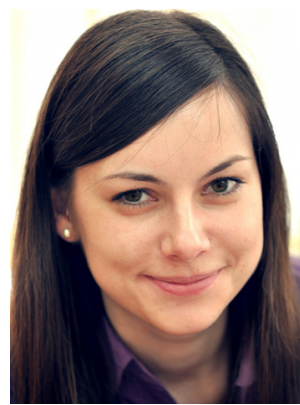

Erika Zaleskienė (Radviliškis, 1986). Bachelor of Forestry (landscape gardening) from Šiauliai University, 2009, Master of Landscape Architecture from Klaipeda University, 2011, Ph. D. student at Kaunas University of Technology since 2012.

ASSISTANT at Śiauliai University, Department of Environmental Research 2010-2013, LECTURER at Šiauliai University, Department of Environmental Research since 2013.

Current and previous research interests: formation of green areas, rural-urban interface, rurban landscapes, landscape aesthetics

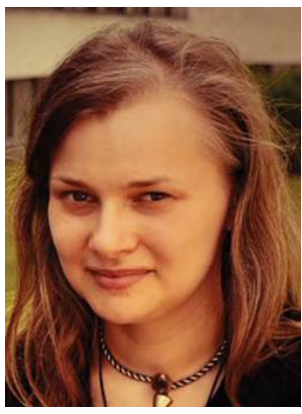

Indrẻ Gražulevičiūtė-Vileniškė (Kaunas, 1981). Bachelor of Architecture, 2003, Master of Land Management, 2005, Doctor of Technological Sciences, 2009, Kaunas University of Technology. LECTURER at Kaunas University of Technology, Faculty of Civil Engineering and Architecture, Department of Architecture and Land Management 2009-2012,

ASSOCIATED PROFESSOR at Kaunas University of Technology, Faculty of Civil Engineering and Architecture, Department of Architecture and Urbanism since 2012.

Current and previous research interests: valuation and preservation of cultural heritage, management of rural-urban interface, sustainable architecture.

\section{CONTACT DATA}

Erika Zaleskienė

Kaunas University of Technology, Faculty of Civil Engineering and Architecture, Department of Architecture and Urbanism

Address: Studentu Str. 48, LT-51367 Kaunas, Lithuania

Phone: +37037451546

E-mail: erika.brinkyte@gmail.com

Indrè Gražulevičiūtè-Vileniškè

Kaunas University of Technology, Faculty of Civil Engineering and Architecture, Department of Architecture and Urbanism

Address: Studentu Str. 48, LT-51367 Kaunas, Lithuania

Tel.: +370 37451546

E-mail: indre.grazuleviciute@ktu.lt 
TABLE I

Summary of Rurban Landscape Management Guidelines.

\begin{tabular}{|c|c|c|c|c|}
\hline 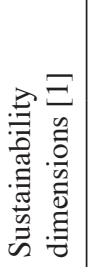 & $\begin{array}{l}\text { Biophysical and social } \\
\text { features that can decrease } \\
\text { resilience }[2,3]\end{array}$ & $\begin{array}{l}\text { Rurban landscape } \\
\text { management guidelines }\end{array}$ & $\begin{array}{c}\text { Relevant rurban landscape } \\
\text { features [4] }\end{array}$ & Relevant level, scale \\
\hline \multirow{9}{*}{ 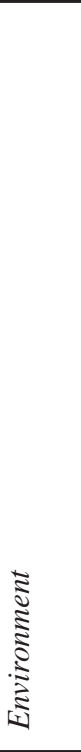 } & \multirow[t]{3}{*}{$\begin{array}{l}\text { Unsustainable resource use } \\
\text { Climate change }\end{array}$} & Multiscale integrated planning & $\begin{array}{l}\text { Interdependent; Complex; } \\
\text { Transient; Contested }\end{array}$ & $\begin{array}{l}\text { International, Regional; National; } \\
\text { Local }\end{array}$ \\
\hline & & $\begin{array}{l}\text { Balanced regional } \\
\text { development }\end{array}$ & Interdependent & International, Regional; National \\
\hline & & $\begin{array}{l}\text { Reserved attitude towards } \\
\text { urban expansion }\end{array}$ & Interdependent; Transient & Local \\
\hline & \multirow[t]{3}{*}{$\begin{array}{l}\text { Loss of biodiversity } \\
\text { Pollution }\end{array}$} & $\begin{array}{l}\text { Application of the concept of } \\
\text { sustainable socio-ecosystem }\end{array}$ & Complex; Remnant; Contested & Local \\
\hline & & $\begin{array}{l}\text { Diversity, multifunctionality } \\
\text { of socio-ecosystems }\end{array}$ & Complex; Remnant; Contested & Local \\
\hline & & $\begin{array}{l}\text { Protection of biodiversity and } \\
\text { eco-compensation }\end{array}$ & $\begin{array}{l}\text { Complex; Remnant; Contested; } \\
\text { Transient }\end{array}$ & Local \\
\hline & \multirow[t]{3}{*}{$\begin{array}{l}\text { Changing disturbance } \\
\text { regimes }\end{array}$} & $\begin{array}{l}\text { Preservation of landscape } \\
\text { heritage }\end{array}$ & $\begin{array}{l}\text { Complex; Remnant; Contested; } \\
\text { Transient }\end{array}$ & National; Local \\
\hline & & $\begin{array}{l}\text { Quality and sustainability of } \\
\text { human living environment }\end{array}$ & $\begin{array}{l}\text { Complex; Remnant; Contested; } \\
\text { Transient; Interdependent }\end{array}$ & Local \\
\hline & & $\begin{array}{l}\text { Ecological land use, } \\
\text { sustainable agriculture }\end{array}$ & $\begin{array}{l}\text { Complex; Remnant; } \\
\text { Interdependent }\end{array}$ & Local \\
\hline \multirow{6}{*}{ 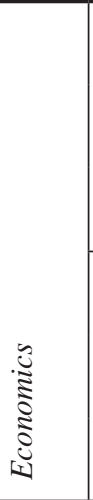 } & \multirow{3}{*}{$\begin{array}{l}\text { Unsustainable resource use } \\
\text { Increased inefficiency } \\
\text { Narrow world views }\end{array}$} & Rational use of resources & $\begin{array}{l}\text { Complex; Contested; } \\
\text { Interdependent }\end{array}$ & $\begin{array}{l}\text { International, Regional; National; } \\
\text { Local }\end{array}$ \\
\hline & & Innovations & $\begin{array}{l}\text { Complex; Remnant; Contested; } \\
\text { Interdependent }\end{array}$ & $\begin{array}{l}\text { International, Regional; National; } \\
\text { Local }\end{array}$ \\
\hline & & Multifunctionality & $\begin{array}{l}\text { Complex; Remnant; Contested; } \\
\text { Interdependent }\end{array}$ & Local \\
\hline & \multirow{3}{*}{$\begin{array}{l}\text { Lack of public participation } \\
\text { and involvement } \\
\text { Inflexible, closed } \\
\text { institutions } \\
\text { Lack of social capital }\end{array}$} & $\begin{array}{l}\text { Self-sufficiency of } \\
\text { communities }\end{array}$ & Complex; Remnant; Contested; & Local \\
\hline & & $\begin{array}{l}\text { Mutually beneficial links with } \\
\text { the city }\end{array}$ & $\begin{array}{l}\text { Complex; Remnant; Transient; } \\
\text { Interdependent }\end{array}$ & Local \\
\hline & & Innovations & $\begin{array}{l}\text { Complex; Remnant; Contested; } \\
\text { Transient; Interdependent }\end{array}$ & National; Local \\
\hline \multirow[b]{4}{*}{ 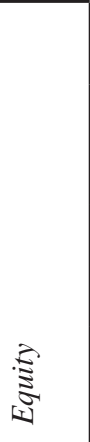 } & Unsustainable resource use & Perceived quality of life & $\begin{array}{l}\text { Complex; Remnant; Contested; } \\
\text { Transient; Interdependent }\end{array}$ & National; Local \\
\hline & \multirow{3}{*}{$\begin{array}{l}\text { Lack of public participation } \\
\text { and involvement } \\
\text { Lack of social memory } \\
\text { Lack of social capital }\end{array}$} & $\begin{array}{l}\text { Involvement of rurban } \\
\text { communities into decision } \\
\text { making }\end{array}$ & Complex; Contested & National; Local \\
\hline & & $\begin{array}{l}\text { Maintenance of social } \\
\text { diversity and diversity of } \\
\text { lifestyles }\end{array}$ & $\begin{array}{l}\text { Complex; Remnant; Contested; } \\
\text { Interdependent }\end{array}$ & Local \\
\hline & & $\begin{array}{l}\text { Development of communities, } \\
\text { formation of local institutions, } \\
\text { organizations, and social links }\end{array}$ & $\begin{array}{l}\text { Complex; Remnant; Contested; } \\
\text { Interdependent }\end{array}$ & Local \\
\hline
\end{tabular}




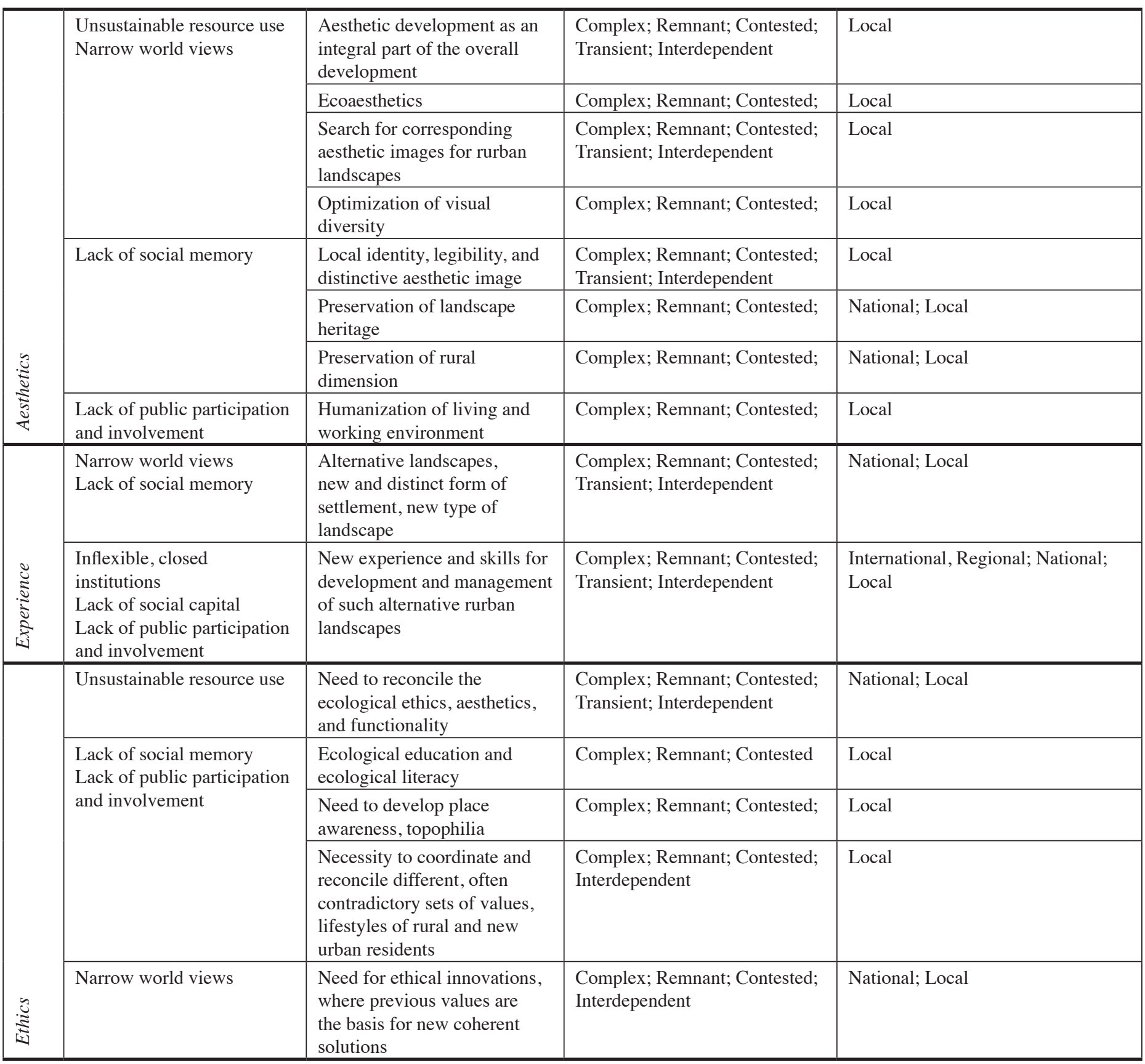

